\title{
Kematangan vokasional dengan \\ kecemasan dalam menghadapi dunia kerja \\ pada mahasiswa tingkat akhir
}

\author{
Ahmad Zulfahmi ${ }^{1}$ dan Devina Andriany ${ }^{2}$
}

\begin{abstract}
The dynamics of problems faced by final year students do not only affect academic achievement but also anxiety in facing the future world of work. University graduates tend to experience career anxiety due to a lack of competence and minimum knowledge of career-related information. This study aims to determine the relationship between vocational maturity and anxiety in dealing with the world of work in final year students, using a correlational quantitative approach. The sample used in the study amounted to 154 people with the criteria of students currently working on their thesis and aged 21-24 years, while the sampling method used accidental sampling technique. The measuring instruments used in this study were the Indonesian Career Adapt-Abilities Scale and the Career Anxiety Scale. Analysis of research data was using Pearson product moment correlation analysis. The results showed that there was a significant negative relationship between vocational maturity and anxiety in facing the world of work in final year students.
\end{abstract}

\section{Keywords}

Anxiety in facing the world of work, early adulthood, final year students, vocational maturity

\section{Pendahuluan}

Semakin tinggi pendidikan seorang tenaga kerja tidak bisa menjamin dirinya terhindar dari status pengangguran khususnya dalam masa resesi, hal ini dikarenakan tenaga kerja terdidik memiliki ekspektasi penghasilan yang tinggi dan cenderung selektif dalam memilih pekerjaan sehingga tidak semua sektor dapat mengatasi fenomena pengangguran pada tenaga kerja terdidik (Yunus et al., 2017). Shamsuddin et al. (2013) mengemukakan dalam penelitiannya bahwa meskipun para fresh graduate sudah cukup terlatih dibidang akademik yang ditempuh akan tetapi mereka dinilai masih kurang dalam hal soft skill, sementara perusahaan-perusahaan sedang mencari tenaga kerja yang seimbang antara akademik, pencapaian dan kemampuan seperti komunikasi, penyelesaian masalah, kemampuan interpersonal, dan kemampuan untuk bekerja secara fleksibel.

Permasalahan di Indonesia adalah banyaknya ketidaksesuaian antara skill atau latar belakang pendidikan yang dimiliki calon tenaga kerja dengan kompetensi yang dibutuhkan oleh perusahaan itu sendiri, sementara calon tenaga kerja terdidik ingin menemukan pekerjaan yang sesuai dengan jurusan yang dimasuki semasa kuliah, maka tingkat kemampuan calon tenaga kerja, jenis kelamin, dan ketertarikan akan suatu pekerjaan dapat meningkatkan kesuksesan calon tenaga kerja dalam memilih pekerjaan yang tepat (Setiawan et al., 2019). Selain itu Pusparisa (2019) menuliskan bahwa penyebab lulusan diploma dan sarjana banyak yang menganggur dikarenakan tiga hal, yaitu keterampilan yang dimiliki tidak sesuai dengan yang dibutuhkan oleh perusahaan, tingginya ekspektasi penghasilan dan status yang akan didapatkan oleh calon tenaga kerja, serta penyediaan lapangan kerja terbatas.

Dinamika terkait permasalahan-permasalahan yang dihadapi oleh pelajar di universitas sejak tahun pertama tidak hanya mempengaruhi pencapaian akademiknya semata, namun juga mempengaruhi kecemasan dalam menghadapi dunia kerja dan tingkat kesulitan menentukan pekerjaan yang akan diambil, salah satu permasalahannya adalah beberapa calon mahasiswa sudah mempunyai tujuan akan pekerjaan yang diinginkan sementara beberapa lainnya bahkan kesulitan untuk masuk kepada fakultas tertentu tanpa peduli pekerjaan seperti apa yang ingin dikejar (Daniels et al., 2011). Sari \& Astuti (2014) menjelaskan bahwa kecemasan dalam menghadapi dunia kerja adalah penilaian subjektif individu akan pencapaian tujuan terkait dunia kerja yang belum pasti sehingga menyebabkan konflik internal, seperti ketakutan, kekhawatiran, pola perilaku menghindar ketika bersinggungan dengan hal-hal seputar dunia kerja. Terdapat beberapa faktor

\footnotetext{
1,2Universitas Muhammadiyah Malang, Indonesia

Korespondensi:

Ahmad Zulfahmi, Fakultas Psikologi Universitas Muhammadiyah Malang

Email: zulfhmiahmd@gmail.com
} 
yang dapat menyebabkan seseorang mengalami kecemasan dalam menghadapi dunia kerja salah satunya adalah konsep diri, yaitu apabila seseorang memiliki konsep diri negatif diantaranya kurang berpengalaman dalam praktek kerja, magang, serta sangat sedikitnya informasi-informasi mengenai dunia kerja maka kecemasan dalam menghadapi dunia kerja akan cenderung tinggi, dikarenakan minimnya pemahaman calon pekerja mengenai gambaran dunia kerja yang akan dihadapinya (Sari \& Astuti, 2014).

Rosliani \& Ariati (2017) mengemukakan faktor internal seperti kognitif, behaviour, dan regulasi diri mempengaruhi tingkat kecemasan dalam dunia kerja, di mana pembentukan persepsi yang negatif terhadap dunia kerja, minimnya ketersediaan untuk aktif berpartisipasi dalam menyelesaikan banyak tugas yang berkaitan dengan kewajiban, serta regulasi diri yang rendah khususnya dalam mengendalikan pikiran dan tindakan dapat meningkatkan kecemasan dalam menghadapi dunia kerja.

Pisarik et al. (2017) mengemukakan beberapa faktor eksternal mahasiswa mengalami kecemasan yang terkait dengan dunia kerja, yaitu: (1) gejala umum kecemasan seperti gangguan tidur; (2) ketidaktersediaan pekerjaan sesuai dengan yang diinginkan sehingga merasa takut; (3) tertekan oleh ekspektasi orang tua dan lingkungan sekitar termasuk dirinya sendiri; (4) kekurangan petunjuk akan bagaimana menghadapi dunia kerja dan bagaimana mengembangkannya; (5) kemampuan yang dimiliki tidak memadai sehingga terjadi distorsi kognitif yang menyebabkan individu tidak percaya akan kemampuan diri dan pengembangan karir yang akan dihadapi; (6) membandingkan kemampuan, pengalaman dan perkembangan karir dengan teman sebaya sehingga mengakibatkan kecemasan; (7) serta cemas yang disebabkan oleh faktor ketidakpastian kemampuan ekonomi maupun kondisi ekonomi di lingkungannya.

Healy (1991) mengemukakan bahwa kecemasan karir berdampak pada perkembangan pengalaman individu, dimana hal tersebut akan mengganggu proses pengambilan keputusan untuk menjalani suatu pekerjaan, maka dibutuhkan pengukuran menyeluruh terkait kemampuan vokasional dan kemampuan pengambilan keputusan terkait karir. Kecemasan menghadapi dunia kerja juga memiliki pengaruh terhadap komitmen terhadap karir yang dipilih, artinya ketika seseorang mempunyai tingkat kecemasan karir yang tinggi maka akan mendorong individu tersebut untuk tidak terburu-buru dalam berkomitmen terhadap pilihan karir yang ada dan bersikap lebih terbuka terhadap eksplorasi karir (Mirah \& Indianti, 2018). Selain itu adversity Intelligence atau kecerdasan dalam mengatasi rintangan juga memiliki hubungan signifikan terhadap kecemasan dalam menghadapi dunia kerja yang berarti bahwa semakin tinggi kemampuan untuk bertahan dan mengatasi kesulitan- kesulitan yang dialaminya, maka akan semakin meningkatkan efikasi diri yang dimiliki individu sehingga mengurangi tingkat kecemasan individu tersebut dalam menghadapi dunia kerja dan begitu pula sebaliknya (Upadianti \& Indrawati, 2020).
Donald Super mengemukakan bahwa individu pada usia 21 sampai 24 tahun memiliki tugas perkembangan vokasional dan telah memasuki periode implementasi, yaitu periode dimana individu menamatkan pendidikan atau pelatihan untuk pekerjaan yang diminati dan mulai memasuki dunia kerja (Zunker, 2002). Kematangan secara vokasional dideskripsikan oleh Moshahid (2017) sebagai kematangan seorang individu secara sikap dan kemampuan berkenaan dengan pengambilan keputusan yang realistis terkait karir sesuai dengan tahap perkembangan seseorang, dimana semakin matang sikap dan kemampuan pengambilan keputusan seseorang maka semakin tinggi tingkat kematangan vokasionalnya. Kematangan vokasional siswa dapat dipengaruhi oleh hasil belajar baik akademik maupun ekstrakurikuler, sehingga siswa lebih mengetahui minat, bakat, potensi maupun kompetensi yang dimiliki dan siap untuk menentukan pilihan terkait dunia kerja yang akan dihadapi (Rozaini \& Purba, 2018).

Hartiningtyas et al. (2016) mengemukakan bahwa self regulated learning dan locus of control internal memiliki korelasi positif terhadap kematangan vokasional. Peserta didik yang mandiri dalam belajar dapat mengetahui apa yang harus dilakukan secara efektif dalam pembelajarannya sehingga lebih paham terkait kompetensi yang dibutuhkan untuk karir di masa mendatang, selain itu individu yang senantiasa menganggap pencapaiannya berada di bawah kontrol dirinya akan cenderung memiliki kematangan vokasional yang baik (Hartiningtyas et al., 2016).

Penelitian yang dilakukan oleh Rohmatulloh (2019) mengemukakan bahwa kematangan vokasional berpengaruh positif terhadap kemandirian menentukan karir dan adaptasi dunia kerja pada siswa, dapat diartikan bahwa siswa yang matang secara vokasional cenderung lebih mampu dalam menyelesaikan konflik terkait pengambilan keputusan yang berkenaan dengan karir, dan mempersiapkan pengetahuan maupun skill yang dibutuhkan ketika akan memasuki dunia kerja nantinya.

Sebagaimana dijelaskan oleh Madan \& Teitge (2013) ialah mahasiswa dalam masa penyelesaian studi di universitas dan sedang mengerjakan tugas akhir, umumnya terlibat dalam proses penelitian dimana pengalaman yang didapatkan dari meneliti tersebut dapat membantu individu agar lebih memahami cara menyeimbangkan antara sistem kerja kolaboratif dan individual, mengetahui bidang minat, dan sebagai awal karir apabila ingin menjadi seorang peneliti. Nurjanah (2018) mengemukakan dalam penelitiannya terhadap lulusan universitas bahwa mahasiswa cenderung memiliki kecemasan ketika ingin menentukan pilihan terkait karir, di mana kecemasan tersebut dipengaruhi oleh beberapa hal, seperti kurangnya rasa percaya diri, banyaknya saingan ketika ingin melamar pekerjaan, kurangnya soft skill yang dimiliki, dan kurangnya informasi mengenai karir yang akan diambil.

Selain itu terdapat hubungan yang signifikan antara kematangan vokasional dengan kecemasan terkait karir pada remaja, dimana remaja dengan tingkat kematangan yang tinggi dalam menentukan keputusan karirnya sendiri 
akan cenderung memiliki konsep diri yang positif sehingga sangat sedikit mengalami kecemasan dalam menghadapi dunia kerja, hal ini dipengaruhi oleh tingginya dukungan dari lingkungan sekitar dan pengembangan soft skill melalui kegiatan-kegiatan ekstrakurikuler yang intensif (Gehlawat, 2019). Adapun penelitian sebelumnya yang dilakukan oleh McGowan (1977) terhadap 126 pelajar remaja mengemukakan hasil bahwa tidak terdapat hubungan antara kematangan vokasional terhadap kecemasan karir, melainkan kecemasan tersebut disebabkan oleh indecisiveness atau ketidakmampuan untuk menentukan pilihan.

Berdasarkan penelitian yang telah dipaparkan sebelumnya oleh Sari \& Astuti (2014), kemudian oleh Nurjanah (2018), maka dapat disimpulkan bahwa individu dengan latar belakang pendidikan perguruan tinggi mengalami kecemasan terkait karir. Selanjutnya aspek kematangan vokasional sebagaimana yang dikemukakan oleh Donald Super (dalam Zunker (2002)) seperti penilaian diri terhadap pemilihan pekerjaan dan pengambilan keputusan pemilihan pekerjaan secara mandiri, memiliki pengaruh terhadap kecemasan dalam menghadapi dunia kerja seperti yang telah dikemukakan sebelumnya oleh Healy (1991) dan juga oleh Pisarik et al. (2017), sehingga kematangan vokasional secara aspek memiliki hubungan dengan kecemasan dalam menghadapi dunia kerja.

Penelitian mengenai hubungan antara kematangan vokasional dengan kecemasan dalam menghadapi dunia kerja pada mahasiswa tingkat akhir sangat relevan dengan kondisi saat ini. Usia 21 sampai 24 merupakan masa menamatkan studi dan mencari pekerjaan. Sedangkan pengangguran kategori lulusan universitas di Indonesia dalam 3 tahun ini terus mengalami peningkatan yang disebabkan oleh hal-hal terkait kurangnya keahlian individu (Pusparisa, 2019). Terdapat gap penelitian di mana Gehlawat (2019) menyebutkan bahwa terdapat hubungan antara kematangan vokasional dengan kecemasan terhadap karir pada remaja, sedangkan McGowan (1977) pada penelitian terdahulu mengemukakan bahwa tidak ada hubungan antara kematangan vokasional dengan kecemasan karir. Selanjutnya, masih sangat sedikit penelitian yang mengkaji mengenai hubungan antara kematangan vokasional dengan kecemasan menghadapi dunia kerja, maka dari itu peneliti ingin mengkaji lebih dalam hubungan antara keduanya melalui pendekatan kuantitatif. Pentingnya penelitian ini dilakukan adalah untuk mengungkap sejauh mana hubungan kematangan vokasional dengan kecemasan menghadapi dunia kerja pada mahasiswa tingkat akhir sehingga lebih terukur dan realistis dalam merencanakan karir, serta sebagai upaya sistematis mengurangi kecemasan menghadapi dunia kerja.

\section{Kecemasan dalam Menghadapi Dunia Kerja}

Kecemasan menurut Schwartz (2000) merupakan keadaan emosional negatif yang ditandai dengan ketegangan berdasarkan firasat dan gejala somatis, seperti jantung berdebar, berkeringat, dan seringkali kesulitan bernafas. Kecemasan berasal dari bahasa latin anxius yang berarti kesesakan atau pencekikan. Kecemasan mempunyai kemiripan dengan ketakutan tetapi dalam fokus yang kurang spesifik, dimana takut adalah respon terhadap ancaman langsung sedangkan cemas lebih kepada kekhawatiran akan bahaya yang tidak dapat diprediksi di masa yang akan datang (Schwartz, 2000). Kemudian Nevid et al. (2006) menjelaskan kecemasan adalah keadaan emosi yang memiliki ciri keterangsangan fisiologis, perasaan tegang yang tidak nyaman, dan perasaan aprehensif berkaitan dengan pemikiran bahwa sesuatu yang buruk akan terjadi

Hammad (2016) mengemukakan bahwa pada dasarnya tidak ada perbedaan mendasar antara kecemasan secara umum dengan kecemasan menghadapi dunia kerja, hanya saja kecemasan karir lebih mengarah pada manifestasi pemikiran dan kepercayaan negatif individu terkait karir di masa depan seperti kekhawatiran akan kegagalan, takut terhadap kesulitan mendapat pekerjaan yang sesuai, maupun perasaan tertekan secara ekonomi dan sosial, dimana seringkali kondisi ini menyebabkan ketegangan dan rasa gugup pada individu ketika bersinggungan dengan hal-hal terkait karir. Kecemasan menghadapi dunia kerja dapat muncul dikarenakan adanya faktor kognitif seperti persepsi negatif yang diliputi rasa kekhawatiran bahwa tidak mampu mengatasi masalah pekerjaan, faktor emosional yaitu rasa tegang akan kondisi menakutkan di masa yang akan datang, dan faktor tuntutan sosial seperti standar keberhasilan atau ekspektasi orang-orang di sekitarnya yang terlalu tinggi (Hanifa, 2017).

Pratiwi \& Irawati (2020) mengemukakan bahwa eksplorasi karir dan kebimbangan karir berpengaruh terhadap kecemasan menghadapi dunia kerja dimana individu yang memiliki informasi yang minim terkait karir dan potensi diri maka cenderung mengalami kebimbangan dalam memilih karir, hal tersebut menyebabkan individu merasa cemas terkait karir masa depan kemudian akan semakin aktif dalam mengeksplorasi lingkungannya sebagai upaya mengurangi kecemasan yang dialami. Individu yang memiliki trait anxiety juga cenderung memiliki kecemasan menghadapi dunia kerja dengan intensitas tinggi, dikarenakan individu dengan trait anxiety secara kognitif akan merasakan ketakutan atas penilaian bahaya yang tidak realistis sehingga kurang baik dalam mengontrol atensi terkait karir (Takil \& Sari, 2021).

Secara umum, kecemasan dibedakan dalam tiga jenis, yaitu: (1) Kecemasan neurosis, adalah rasa cemas akibat bahaya yang tidak diketahui yang muncul dari dorongan id dan merupakan ketakutan akan hukuman yang terjadi akibat pemuasan kebutuhan; (2) Kecemasan moral, yaitu kecemasan yang berasal dari konflik antara ego dan superego karena merasa gagal untuk berperilaku berdasarkan moral yang diyakini, biasanya dipengaruhi oleh pengalaman akan hukuman yang diterima dari melanggar hukum moral; (3) Kecemasan realistik, merupakan perasaan tidak menyenangkan dan tidak 
spesifik berkaitan dengan kemungkinan adanya bahayabahaya nyata yang berasal dari luar diri individu (Feist \& Feist, 2012) .

Stuart (2006) mengelompokkan aspek-aspek kecemasan menjadi tiga, yaitu: (1) Aspek perilaku, misalnya gelisah, ketegangan fisik, berbicara cepat, menarik diri dari hubungan interpersonal, melarikan diri dari masalah, menghindar, dan sangat waspada; (2) Aspek kognitif, seperti perhatian teralih, sulit berkonsentrasi, mudah lupa, bingung, takut tidak mempunyai kendali, keterhambatan berpikir; (3) Aspek afektif, diantaranya tidak sabaran, ketakutan, gugup, kekhawatiran, perasaan bersalah, dan malu.

Chen (2005) mengemukakan bahwa terdapat empat dimensi kecemasan dalam menghadapi dunia kerja pada mahasiswa, yaitu: (1) Personal ability, adalah ketika individu lebih mengenali diri sendiri dan memiliki kemampuan sesuai dengan kebutuhan pekerjaan maka akan berdampak pada peningkatan kepercayaan diri dan pengurangan kecemasan; (2) Irrational beliefs about employment, merupakan kekhawatiran akan ketidaksesuaian antara nilai, perkembangan kemampuan individu yang telah dibangun, preferensi, dengan realitas pada kebutuhan pekerjaan yang dipilih di masa depan; (3) Professional education training, kekhawatiran bahwa keahlian atau pengalaman yang dimiliki akan senantiasa bertolak belakang dengan ketertarikan pribadi; dan (4) Employment environment, kekhawatiran individu akan minimnya informasi terkait pekerjaan, seperti kondisi ekonomi, pendapatan, maupun dinamika ketenagakerjaan yang tidak sesuai dengan ekspektasi.

\section{Kematangan Vokasional}

Kematangan vokasional terdiri dari kata kematangan dan vokasional. Kematangan menurut Monks et al. (2001) adalah kesiapan individu dalam melaksanakan tugas-tugas perkembangan tertentu dan kemampuan untuk berfungsi dalam tingkat yang lebih tinggi sebagai hasil pertumbuhan. Sedangkan vokasional adalah pengetahuan yang mencakup berbagai macam keterampilan pada individu untuk menghadapi kehidupan nyata agar memiliki fungsi di lingkungan sosialnya (Sudira, 2012). Kematangan vokasional dapat diartikan sebagai perbedaan individual terkait kesiapan menentukan pilihan mengenai karir, rencana masa depan, dan peranan sebagai pekerja (Gash \& Khan, 2014). Istilah kematangan vokasional yang sekarang banyak disebut sebagai kematangan karir pertama kali diperkenalkan oleh Donald Super beberapa puluh tahun yang lalu, Super tertarik untuk mengkaji karir individu yang berkaitan dengan perilaku dalam menentukan pilihan (karir) sebagai suatu manifestasi ide yang penting dalam diri individu dan sebagai proses kunci dalam perkembangannya (Lakesh \& Khan, 2018).

Super \& Kidd (1979) mengemukakan bahwa kematangan vokasional adalah kesiapan individu secara sikap maupun kemampuan untuk membuat keputusan mengenai karir, di mana seseorang yang matang secara vokasional dianggap lebih tertuju pada tujuan yang ingin dicapai dan lebih realistis. Kemampuan vokasional atau perkembangan karir tersebut senantiasa berubah tergantung pada umur, status dalam masyarakat, kemampuan, perubahan kondisi sosial dan ekonomi, dan perubahan kondisi fisik juga mental (Super \& Kidd, 1979). Perkembangan vokasional seseorang mengacu pada kematangan individu terkait sikap dan kompetensi yang dibangun sepanjang perjalanan usianya (Crites, 2013). Zunker (2002) mengemukakan lima tahapan perkembangan vokasional berdasarkan tahapan kehidupan, yaitu: (1) Growth stage (masa kelahiran hingga usia 14 tahun), individu menjadi waspada terhadap masa depan, peningkatan kontrol diri akan kehidupannya sendiri, meyakinkan diri akan kesuksesan di sekolah dan pekerjaan, dan memperoleh sikap kerja yang kompeten dan nilai kerja; (2) Exploratory stage (usia 15 sampai 25 tahun), merupakan masa individu memperoleh peran di masyarakat dan menyempurnakan konsep diri untuk selanjutnya diuji oleh realitas; (3) Establishment stage (usia 26 sampai 45 tahun), masa di mana individu lebih dewasa dalam menyeimbangkan, melanjutkan, dan berproses dalam posisi pada karirnya; (4) Maintenance stage (46 sampai 65 tahun), masa dimana individu mempertahankan, mengikuti dan berinovasi perkembangan karirnya; (5) Stage of decline or disengagement (66 tahun ke atas), masa penurunan aktivitas kerja dan perencanaan pensiun.

Super menambahkan lima tugas perkembangan vokasional manusia, yaitu: (1) Crystallization (usia 14 hingga 18 tahun), perencanaan dan perkembangan lebih lanjut terhadap tujuan pekerjaan yang bersifat sementara; (2) Specification (usia 18 hingga 21 tahun), membangun tujuan vokasional seperti keahlian-keahlian tertentu; (3) Implementation (usia 21 hingga 24 tahun), mengikuti pembelajaran dan pelatihan untuk selanjutnya ditempatkan dalam suatu pekerjaan; (4) Stabilization (usia 24 hingga 35 tahun), membangun dan mengembangkan pilihan karir dalam pekerjaan; (5) Consolidation (usia 35 tahun ke atas), berproses didalam karir yang dipilih (Stead \& Watson, 2006).

Individu dengan tingkat kematangan vokasional yang tinggi akan cenderung merasa yakin akan kesuksesan melakukan tugas-tugas yang berkaitan dengan pengambilan keputusan karir dan merasa puas dengan pekerjaan yang dilakukan, hal ini dikarenakan individu yang matang secara vokasional mampu menyesuaikan ketertarikan dengan tugas pada pekerjaan yang diinginkan (Kim et al., 2018). Hal serupa juga dikemukakan oleh Harlow \& Bowman (2016) bahwa mahasiswa yang berada dalam komunitas cenderung memiliki tingkat kematangan vokasional yang tinggi dan yakin terhadap pilihan karir juga tugastugasnya, hal ini ditunjang oleh ketersediaan informasi terkait pekerjaan, pengarahan mengenai bagaimana menetapkan tujuan, dan peningkatan eksplorasi diri. 
Crites dan Savickas (dalam Watkins \& Campbell (2000)) mengemukakan bahwa terdapat enam aspek kematangan vokasional, yaitu: (1) Career planning, merupakan kemampuan individu untuk mencari dan mempelajari informasi mengenai karir yang ada, termasuk mengikuti pelatihan sesuai dengan kebutuhan pekerjaan yang diinginkan; (2) Career exploration, merupakan keinginan individu untuk mencari informasi langsung melalui sumber informasi utama pekerjaan tersebut maupun melalui sumber lainnya yang terpercaya; (3) Knowledge about making career decisions, adalah pengetahuan individu tentang langkah menentukan pilihan karir, khususnya bagaimana mempersiapkan pilihan karir berdasar dari pengetahuan yang dimiliki; (4) Knowledge of the world of work information, adalah pengetahuan individu terkait ketertarikan dan kemampuannya sendiri sehingga dapat lebih memahami dinamika dunia kerja khususnya hal-hal yang berhubungan dengan perilaku individu; (5) Knowledge of preferred occupational group, merupakan pengetahuan akan tugas pada pekerjaan yang diinginkan, seperti apa saja yang dibutuhkan di dalam pekerjaan tersebut baik secara fisik maupun mental, dan ketertarikan juga alasan yang tepat untuk memilih pekerjaan tersebut; (6) Realization of career decisions, adalah pemahaman yang baik akan kekuatan dan kelemahan diri individu dihubungkan dengan pilihan karir yang diinginkan, termasuk faktor apa saja yang mendukung pilihan karir, pemilihan alternatif pekerjaan, dan kemampuan melihat peluang terkait pilihan karir yang diinginkan.

Savickas (1997) dalam penelitiannya membahas kematangan vokasional sebagai adaptabilitas, yaitu dasar perilaku untuk mengantisipasi tugas, transisi maupun trauma terhadap peran kerja yang pada beberapa aspek dapat mempengaruhi integrasi sosial. Terdapat empat dimensi adaptabilitas karir, yaitu: (1) Concern, memperhitungkan masa depan vokasional sehingga menjadi lebih bertanggung jawab untuk membentuk dirinya sendiri menggunakan sikap disiplin, usaha, dan kerja keras; (2) Control, mencoba untuk mempersiapkan masa depan vokasional; (3) Curiosity, menunjukkan rasa keingintahuan dengan menjelajahi kemungkinan yang akan terjadi pada diri sendiri maupun skenario masa depan; (4) Confidence, memperkuat kepercayaan diri untuk mengejar hal yang menjadi aspirasi individu (Savickas, 1997).

\section{Kematangan Vokasional dan Kecemasan dalam Menghadapi Dunia Kerja}

Stead \& Watson (2006) mengemukakan bahwa individu pada usia 21 hingga 24 tahun sedang memasuki masa implementasi yaitu masa menamatkan edukasi dan mempersiapkan memasuki dunia kerja, dengan kata lain mahasiswa tingkat akhir saat ini menempuh periode pembelajaran dan pelatihan sebelum nantinya menempati posisi dalam suatu pekerjaan. Akan tetapi mahasiswa tingkat akhir cenderung mengalami perasaan cemas ketika akan menghadapi dunia kerja dikarenakan faktor internal seperti kemampuan diri sendiri maupun faktor eksternal seperti kekhawatiran akan kondisi sosial ekonomi dan kurangnya informasi terkait pekerjaan yang diinginkan (Pisarik et al., 2017).

Terdapat kesesuaian antara aspek kematangan vokasional dengan dimensi kecemasan dalam menghadapi dunia kerja. Dimensi kecemasan dalam menghadapi dunia kerja sebagaimana dikemukakan oleh Chen (2005) adalah tidak memiliki kemampuan sesuai dengan kebutuhan pekerjaan (personal ability), minimnya informasi terkait pekerjaan (employment environment), dan ketidaksesuaian antara keahlian dengan preferensi pribadi (professional education training), sedangkan Crites dan Savickas (dalam Watkins \& Campbell (2000)) mengemukakan bahwa individu dikatakan matang secara vokasional apabila memenuhi beberapa aspek termasuk mempersiapkan keahlian yang dibutuhkan (career planning), memiliki informasi yang cukup terkait pekerjaan (knowledge of the world of work information), dan membuat keputusan dengan mempertimbangkan kesesuaian antara keahlian pribadi dengan pilihan karir yang diinginkan (realization of career decisions).

Vignoli (2015) mengemukakan bahwa kurangnya kompetensi, eksplorasi diri, dan informasi terkait karir pada pekerjaan yang diinginkan dapat berdampak pada tingginya kecemasan karir pada individu, sehingga individu tidak realistis dalam menentukan pilihan karir. Dimensi kematangan vokasional diantaranya perencanaan karir, eksplorasi karir, dan pengetahuan mengenai karir yang akan dipilih (Watkins \& Campbell, 2000). Individu yang realistis dalam menentukan pilihan-pilihan terkait karir yang akan dipilih dan senantiasa merujuk pada sikap dan kompetensi yang telah dibangun sepanjang hidup merupakan individu yang matang secara vokasional (Super \& Kidd, 1979).

Hal ini didukung oleh penelitian Sari \& Astuti (2014) yang mengemukakan bahwa apabila individu memahami diri sendiri dan memiliki kemampuan yang dibutuhkan dalam karir, mempunyai cukup informasi dan akses informasi yang memadai terkait karir, serta manajemen diri yang baik maka dapat mengurangi tingkat kecemasan dalam menghadapi dunia kerja. Penelitian di atas dibuktikan oleh Gehlawat (2019) yang menjelaskan bahwa remaja dengan kecenderungan membangun kematangan vokasional, seperti meningkatkan soft skill, mengeksplorasi lingkungan, maupun mengikuti banyak kegiatan ekstrakurikuler memiliki tingkat kepercayaan diri dan kematangan vokasional yang tinggi, hal ini tentunya berdampak pada tingkat kecemasan karir yang rendah.

\section{Hipotesa}

Terdapat hubungan yang signifikan antara kematangan vokasional dengan kecemasan dalam menghadapi dunia kerja pada mahasiswa tingkat akhir. 


\section{Metode}

Penelitian ini menggunakan pendekatan kuantitatif yaitu metode penelitian ilmiah dimana data dikumpulkan menggunakan alat ukur yang objektif dan baku, lalu diolah menggunakan analisis data statistik. Desain penelitian yang digunakan adalah penelitian korelasional. Penelitian korelasional dilakukan oleh peneliti untuk mengetahui ada tidaknya hubungan antara dua variabel tanpa melakukan perubahan, tambahan atau manipulasi terhadap data yang ada.

\section{Subjek Penelitian}

Subjek dari penelitian ini ialah mahasiswa tingkat akhir, dengan kriteria sebagai berikut: (1) Sedang mengerjakan tugas akhir (Skripsi); dan (2) Berusia 21 sampai 24 tahun pada tahun 2020. Teknik sampling yang digunakan adalah accidental sampling, yaitu penentuan sampel dimana populasi yang dipilih ialah kategori dengan akses paling mudah bagi peneliti, individu dapat dijadikan sampel apabila orang tersebut dipandang memenuhi kriteria tertentu yang telah dipaparkan, sehingga hasil penelitian yang dilakukan menjadi lebih representatif.

Jumlah subjek yang digunakan dalam penelitian ini ialah sebanyak 154 orang mahasiswa tingkat akhir yang terdiri dari 30 subjek laki-laki $(19.48 \%)$ dan 124 subjek perempuan $(80.51 \%)$ dengan rentang usia 21 sampai 24 tahun dan juga sedang mengerjakan tugas akhir. Sebanyak 124 subjek $(80.50 \%)$ menempuh pendidikan di universitas di pulau Jawa, dengan mayoritas sebanyak 53 subjek (34.60\%) berasal dari Fakultas Psikologi. Adapun NonJawa terdiri dari universitas-universitas yang berada di Sulawesi, Sumatera, Kalimantan, dan Nusa Tenggara.

Jumlah populasi yang digunakan dalam penelitian ini tidak diketahui (non-probability sampling) sehingga penentuan jumlah sampel merujuk pada Widiyanto (2008), yaitu minimal 100 mahasiswa tingkat akhir.

\section{Variabel dan Instrumen Penelitian}

Pada penelitian ini terdapat dua variabel, yakni variabel bebas (X) dan variabel terikat (Y). Adapun yang menjadi variabel bebas $(\mathrm{X})$ adalah kematangan vokasional sedangkan variabel terikat (Y) adalah kecemasan dalam menghadapi dunia kerja.

Kematangan vokasional yang dimaksud dalam penelitian ini adalah kesiapan individu untuk menyelesaikan tugas yang berhubungan dengan pengambilan keputusan dalam karir, mengacu pada kesesuaian antara perilaku individu dengan perilaku yang dibutuhkan dalam karir ditingkatan usia tertentu. Instrumen penelitian menggunakan Career Adapt-Abilities Scale (CAAS) Indonesian Form yang dikembangkan oleh Sulistiani et al. (2019) berdasarkan dimensi kematangan vokasional yang dipaparkan Savickas \& Porfeli (2012). Skala ini terdiri dari 24 aitem yang disusun berdasarkan empat dimensi kematangan vokasional, yaitu perhatian, kontrol, rasa penasaran, dan kepercayaan diri. Contoh itemnya ialah "Merencanakan bagaimana cara mencapai tujuan saya", kemudian "Mencari tahu alternatif karir". Validitas dan reliabilitas alat ukur yang digunakan sangat baik dengan nilai Cronbach's alpha sebesar 0.91 .

Kecemasan menghadapi dunia kerja yang dimaksud dalam penelitian ini adalah pemikiran negatif atau kekhawatiran terkait karir masa depan, seperti takut akan kegagalan, takut tidak mendapat pekerjaan yang sesuai, maupun perasaan tertekan ketika bersinggungan dengan hal- hal yang berhubungan dengan karir masa depan. Instrumen penelitian yang digunakan adalah Career Anxiety Scale (CAS) yang dikembangkan oleh Tsai et al. (2017), berdasarkan dimensi kecemasan menghadapi dunia kerja oleh Chen (2005). Skala ini terdiri dari 25 aitem yang disusun berdasarkan empat dimensi kecemasan menghadapi dunia kerja, yaitu kemampuan personal, kepercayaan yang tidak rasional terhadap pekerjaan, lingkungan pekerjaan, dan pelatihan pendidikan profesional. Contoh itemnya ialah "Saya tidak akan cemas terhadap pekerjaan di masa depan apabila saya memiliki sertifikat profesional", dan "Saya tidak akan cemas terhadap pekerjaan di masa depan apabila saya memiliki kemampuan berbahasa asing yang baik". Setelah dilakukan uji validitas dan reliabilitas, didapatkan validitas maupun reliabilitas yang baik dengan nilai Cronbach's alpha sebesar 0.91 .

Kedua alat ukur dalam penelitian ini menggunakan skala likert yang disusun dengan item yang mendukung konsep (favorable) dan item yang tidak mendukung konsep (unfavorable). Pada setiap item kelompok pertanyaan mempunyai empat pilihan jawaban, yaitu: Sangat Sesuai (SS), Sesuai (S), Tidak Sesuai (TS), dan Sangat Tidak Sesuai (STS).

\section{Prosedur dan Analisis Data}

Penelitian ini menggunakan beberapa prosedur sebagai berikut: tahap persiapan, yaitu merumuskan latar belakang permasalahan berdasarkan fenomena yang terjadi, menetapkan variabel yang akan diteliti, serta pengkajian secara teoritik materi guna lebih mendalami variabel yang akan diteliti. Selanjutnya peneliti melakukan adaptasi dan uji coba (try out) instrumen penelitian skala kecemasan menghadapi dunia kerja. Data yang diperoleh dari uji coba kemudian dianalisis menggunakan program Statistical Package for Social Science (SPSS) 26 guna memperoleh validitas dan reliabilitas item skala tersebut.

Tahap selanjutnya peneliti mengambil data penelitian dengan cara menyebarkan skala melalui media daring google form yang disebarkan melalui media sosial (Instagram, Twitter, dan WhatsApp) kepada individu yang telah memenuhi kriteria untuk dijadikan subjek penelitian. Kemudian hasil dari jawaban subjek untuk masing-masing skala diinput ke dalam microsoft excel sesuai dengan pengkodean dari skala likert. Setelah itu didapatkan 
Tabel 1. Deskripsi Data Variabel

\begin{tabular}{lcr}
\hline Variabel & M & SD \\
\hline Kematangan vokasional & 95.0 & 15.0 \\
$\begin{array}{l}\text { Kecemasan dalam menghadapi } \\
\text { kerja }\end{array}$ & 57.0 & 12.0 \\
\hline
\end{tabular}

responden sebanyak 160 dengan 6 responden yang gugur dikarenakan tidak memenuhi kriteria subjek penelitian.

Tahap terakhir, peneliti melakukan analisa hasil yang didapatkan dari subjek penelitian. Data- data yang ada kemudian diinput lalu diolah dengan menggunakan program Statistical Package for Social Science (SPSS) 26. Pertama-tama peneliti menguji normalitas data, selanjutnya peneliti melakukan analisa uji korelasi menggunakan uji korelasi product moment pearson guna mengetahui hubungan antara kematangan vokasional dengan kecemasan dalam menghadapi dunia kerja.

\section{Hasil}

Data yang diperoleh kemudian dilakukan uji normalitas menggunakan metode Kolmogorov-Smirnov, dimana nilai residual dapat dikatakan berdistribusi dengan normal jika nilai signifikansi di atas 0.05. Hasil uji normalitas yang dilakukan pada kedua variabel dikatakan normal karena menunjukkan nilai signifikansi $p=0.083$.

Deskripsi data variabel dapat dilihat pada Tabel 1, sebanyak 106 subjek (68.8\%) masuk dalam kategori kematangan vokasional sedang dengan rata-rata skor sebesar 95, sedangkan variabel kecemasan dalam menghadapi dunia kerja sebanyak 98 subjek (63.6\%) masuk dalam kategori sedang dengan rata-rata skor sebesar 57. Selanjutnya nilai standar deviasi variabel kematangan vokasional sebesar 15, dan variabel kecemasan dalam menghadapi dunia kerja sebesar 12. Adapun kategorisasi data kedua variabel dilakukan menggunakan uji statistik empirik sehingga diketahui frekuensi berdasarkan kategori pada tiap variabel.

Selanjutnya korelasi variabel kematangan vokasional dengan jenis kelamin didapatkan nilai koefisien korelasi sebesar -0.196, kemudian antara variabel kecemasan dalam menghadapi dunia kerja dengan jenis kelamin diperoleh nilai r sebesar 0.204. Artinya terdapat hubungan yang signifikan antara jenis kelamin dengan kematangan vokasional maupun jenis kelamin dengan kecemasan dalam menghadapi dunia kerja $(p<0.05)$. Sedangkan terkait variabel usia, universitas, dan fakultas tidak berhubungan dengan kematangan vokasional ataupun kecemasan dalam menghadapi dunia kerja.

Hasil uji korelasi menggunakan pearson product moment diperoleh hubungan negatif yang signifikan antara kematangan vokasional dengan kecemasan dalam menghadapi dunia kerja pada mahasiswa tingkat akhir $(\mathrm{r}=-0.251 p=0.002)$. Nilai $\mathrm{r}^{2}$ yang diperoleh sebesar 0.063 , artinya terdapat kontribusi variabel kematangan vokasional terhadap kecemasan dalam menghadapi dunia kerja sebanyak $6.3 \%$ sedangkan $93.7 \%$ sisanya melibatkan kontribusi faktor-faktor lain.

\section{Diskusi}

Berdasarkan penelitian yang telah dilakukan, diperoleh hasil yaitu terdapat hubungan negatif yang signifikan antara kematangan vokasional dengan kecemasan dalam menghadapi dunia kerja pada mahasiswa tingkat akhir $(\mathrm{r}=-0,251 ; p<0.05)$. Hal tersebut berarti bahwa semakin tinggi kematangan vokasional maka semakin rendah kecemasan dalam menghadapi dunia kerja pada mahasiswa tingkat akhir, sebaliknya semakin rendah kematangan vokasional maka semakin tinggi kecemasan dalam menghadapi dunia kerja pada mahasiswa tingkat akhir. Maka dari itu hipotesa bahwa terdapat hubungan yang signifikan antara kematangan vokasional dengan kecemasan dalam menghadapi dunia kerja pada mahasiswa tingkat akhir dapat diterima.

Hasil penelitian ini mendukung penelitian Daniels et al. (2011) yang mengemukakan bahwa kurangnya persiapan kemampuan terkait karir, kesulitan dalam menentukan pilihan karir secara mandiri, dan minimnya informasi untuk mendukung pilihan terkait karir dapat menjadi salah satu aspek yang turut meningkatkan kecemasan karir pada mahasiswa tingkat akhir. Hal tersebut kemudian diperkuat oleh Shin \& Lee (2019) dalam penelitiannya, menyatakan bahwa ketertarikan individu terhadap pekerjaan yang ideal secara subjektif, kemauan berusaha untuk menambah pengetahuan guna menyiapkan karir, dan kontrol terhadap diri sendiri merupakan komponen utama adaptabilitas karir dan faktor tersebut memiliki hubungan negatif dengan kecemasan terkait karir masa depan. Sebaliknya, adaptabilitas karir yang rendah, perilaku menghindar, juga menarik diri dari ketidakpastian dalam proses menentukan pilihan karir secara positif berhubungan dengan tingginya tingkat kecemasan karir pada siswa SMA dan mahasiswa universitas di Cina (Xu et al., 2016).

Sebagaimana dapat dilihat pada hasil penelitian, dijelaskan bahwa derajat hubungan antara variabel kematangan vokasional dengan kecemasan dalam menghadapi dunia kerja ialah rendah. Hasil tersebut mendukung penelitian Gehlawat (2019) yang menyatakan bahwa terdapat korelasi yang rendah antara kematangan vokasional dengan kecemasan karir pada remaja, sedangkan terdapat korelasi tinggi antara kematangan vokasional dengan kecemasan karir pada remaja ketika dimediasi oleh variabel konsep diri. Hal ini dikarenakan faktor lingkungan seperti orang tua dan guru sangat berpengaruh dalam mendorong remaja untuk mempertahankan juga meningkatkan kemampuan, serta reinforcement positif membantu remaja membangun konsep diri yang positif sehingga remaja dapat mengembangkan keahlian secara lebih efisien (Gehlawat, 2019). Membuat pilihan karir terkadang menjadi sebuah permasalahan diantara pelajar karena mereka masih merasa samar terhadap pembuatan keputusan karir berdasarkan keahlian yang akan dijalani 
di masa depan, rata-rata pelajar di masa ini membuat pilihan karir berdasarkan kriteria yang diatur oleh keluarga maupun kelompok yang menyokong pembelajarannya, kurangnya penyediaan informasi terkait pengembangan karir maupun terkait karir itu sendiri turut memperburuk situasi, maka dari itu dibutuhkan konseling karir dan pedoman yang jelas dalam mendukung peningkatan mutu dan kematangan vokasional pelajar (Turner \& Lapan, 2003).

Dari hasil penelitian diketahui bahwa dari total 154 subjek, mayoritas mahasiswa tingkat akhir sebanyak 106 $(68,80 \%)$ termasuk dalam kategori kematangan vokasional sedang. Berdasarkan hasil yang telah didapatkan, diketahui bahwa faktor yang mempengaruhi kematangan vokasional sedang pada mahasiswa tingkat akhir terletak pada aspek curiosity yang rendah, dimana hal tersebut melibatkan rasa keingintahuan individu terhadap lingkungan kerja masa depan, pendalaman terhadap informasi diri sendiri terkait karir, peluang untuk mengembangkan diri, maupun alternatif-alternatif dalam menentukan pilihan karir. Hal ini sejalan dengan penelitian yang dilakukan oleh Bahrinsyah (2018) terhadap 240 mahasiswa universitas di Yogyakarta, mengemukakan hasil bahwa mahasiswa universitas cenderung memiliki kematangan vokasional sedang atau moderate, dengan kata lain mahasiswa pada kategori ini memiliki kecenderungan untuk merasakan ketidakstabilan dalam hal kematangan vokasional apabila tidak diintervensi atau difasilitasi dengan baik.

Hasil uji hubungan yang telah dilakukan mengemukakan hasil bahwa terdapat hubungan antara jenis kelamin dengan kematangan vokasional mahasiswa tingkat akhir. Hal ini didukung oleh penelitian Patton \& Creed (2002) yang menyatakan bahwa jenis kelamin turut mempengaruhi kematangan vokasional individu, dimana wanita cenderung lebih matang ketimbang pria dikarenakan tingginya asertivitas wanita terkait tujuan, sehingga mengarah pada pengembangan sikap karir yang positif dan kepemilikan terhadap informasi karir yang lebih banyak, sikap karir positif yang dimaksud ialah kecenderungan wanita untuk lebih berkomitmen dalam mengembangkan karirnya, selain itu wanita menunjukkan keterkaitan lebih pada tugas penting dalam proses membuat keputusan karir.

Penelitian yang dilakukan oleh Prideaux \& Creed (2001) menyebutkan bahwa seringkali career indecision atau ketidakmampuan untuk menentukan pilihan terkait karir dipandang sebagai salah satu faktor yang menghambat perkembangan kematangan vokasional, dimana career indecision dianggap sebagai hasil dari kekurangan informasi individu atas dirinya sendiri maupun atas dunia kerja yang akan dihadapi. Ketidakstabilan dalam hal kematangan vokasional tersebut dapat berdampak pada ketidakmampuan menentukan pilihan karir dan kecemasan karir, dimana individu kesulitan dalam mengidentifikasi minat, keahlian, perilaku yang berhubungan dalam pengambilan keputusan terkait karir sehingga sulit menentukan pilihan juga menderita atas perasaan dan pemikiran negatif sebagai dampak dari pilihan karir yang diambil (Daniels et al., 2011).
Terdapat beberapa faktor lain yang mempengaruhi tinggi-rendahnya kematangan vokasional individu sebagaimana disampaikan oleh Eliana et al. (2016), seperti: (1) Biosocial, yaitu kapasitas dalam menerima tanggung jawab sosial atas pilihan dan rencana; (2) Environmental, berkaitan dengan pekerjaan dan pendidikan orang-orang di sekitar individu; (3) Vocational, aspirasi karir dan derajat keterhubungan antara aspirasi dengan ekspektasi; (4) Personality Characteristics, termasuk di dalamnya konsep diri, keahlian khusus, nilai atau norma, dan kebermaknaan hidup; (5) Individual Achievement, di mana pencapaian individu berhubungan dengan kematangan vokasional seperti tingkat pendidikan maupun partisipasi di sekolah dan aktivitas luar sekolah. Kematangan vokasional pasti memiliki perbedaan baik antara siswa sekolah menengah dengan mahasiswa, antara satu kelas (sekolah) dengan kelas lainnya, maupun antara suatu daerah dengan daerah lainnya, perbedaan pada aspek sosio-kultural, etnisitas, dan ekonomi dapat menjadi faktor penyebab perbedaan pengembangan karir individu pada suatu kelompok, kemudian tingkat edukasi memegang peranan dalam peningkatan kematangan vokasional individu dimana sekolah dengan fasilitas dan akses informasi lebih banyak akan cenderung menghasilkan individu yang matang secara vokasional.

Ismail et al. (2018) mengemukakan bahwa kematangan vokasional pada pelajar memegang peranan penting terkhusus dalam pencapaian akademik maupun karir masa depan, dimana individu yang matang secara vokasional dapat cenderung mengalami peningkatan dalam pencapaian akademik atau academic achievement, selain itu aspek intelegensi berdasarkan academic achievement tersebut sangat berpengaruh terhadap pengembangan sikap karir individu. Kematangan vokasional juga berdampak positif pada pengurangan reaksi stres dimana individu dengan kematangan karir yang tinggi akan cenderung membuat keputusan karir yang ideal dengan mengandalkan dirinya sendiri, sehingga mengurangi tekanan akibat kebingungan dan menyegerakan pemilihan keputusan karir tanpa bergantung pada kelompok seperti teman dan orang tua (Hidayat \& Alsa, 2018).

Terkait kecemasan dalam menghadapi dunia kerja, sebanyak 98 subjek (63.60\%) masuk dalam kategori sedang, artinya mayoritas mahasiswa tingkat akhir dalam penelitian ini terkadang masih mengalami ketidakpastian akan karir yang ingin dipilih, kemampuan dan ketertarikan pribadi, juga terkait pekerjaan seperti apa yang sesuai baginya. Berdasarkan hasil penelitian, dapat diketahui bahwa hal ini dipengaruhi oleh aspek employment environment yang tinggi pada kecemasan menghadapi dunia kerja mahasiswa tingkat akhir, yaitu berkaitan dengan persepsi negatif akan pemberitaan media mengenai kondisi keterpurukan ekonomi negara, banyaknya saingan ketika ingin berkompetisi di dunia kerja, angka pengangguran yang tinggi, dan kekhawatiran akan ketidaksesuaian antara ekspektasi dengan realita dunia kerja yang akan dihadapi nanti. Hal ini didukung oleh penelitian Mahmud 
et al. (2020) yang memaparkan hasil bahwa kekhawatiran akan kondisi di sekitar individu memiliki pengaruh langsung terhadap kecemasan menghadapi karir masa depan, seperti kondisi dunia yang dilanda wabah coronavirus disease (COVID-19) menyebabkan mahasiswa tingkat akhir merasa takut akan ancaman berkaitan dengan kondisi ekonomi negara dan dampaknya terhadap lingkungan kerja yang calon pekerja akan hadapi.

Berdasarkan hasil penelitian juga diketahui bahwa jenis kelamin memiliki hubungan yang signifikan terhadap kecemasan dalam menghadapi dunia kerja pada mahasiswa tingkat akhir. Hasil ini didukung oleh Hammad (2016) melalui penelitiannya yang mengemukakan bahwa jenis kelamin turut berpengaruh pada tingginya kecemasan dalam menghadapi dunia kerja, dimana laki-laki cenderung lebih cemas dibandingkan wanita dikarenakan pembagian peran kerja berdasarkan jenis kelamin pada beberapa budaya, contohnya di Arab Saudi laki-laki memiliki tanggung jawab untuk menafkahi keluarga secara penuh dengan kebutuhan yang cukup beragam dan tingginya biaya hidup, sehingga memunculkan persepsi akan tangungan beban berat ketika memasuki dunia kerja nantinya.

Terdapat beberapa hal yang dapat mempengaruhi kecemasan karir pada mahasiswa, salah satunya dikemukakan oleh Deer et al. (2018) mengemukakan bahwa career selfefficacy turut mengurangi kecemasan menghadapi dunia kerja pada mahasiswa terlebih apabila hal tersebut didasari oleh dukungan lingkungan sekitar dan kepercayaan diri yang didapatkan dari pengalaman seperti magang ataupun media edukasi lainnya. Selain itu career uncertainty atau career indecision memainkan peran krusial terhadap kecemasan karir dimana individu yang tidak bisa menentukan pilihan karir masa depannya akan cenderung merasa cemas, begitu pula sebaliknya bahwa individu yang mengalami kecemasan karir akan mempengaruhi kemampuan dalam menentukan pilihan karir dan merasakan hal-hal seperti keraguan, kebingungan, sehingga tidak mampu untuk menentukan pilihan karirnya sendiri (Tsai et al., 2017).

Penelitian yang dilakukan oleh Vignoli (2015) mengemukakan hasil bahwa kecemasan karir dan kebimbangan karir memiliki pengaruh positif yang signifikan terhadap eksplorasi karir, dimana individu yang cemas akan karirnya cenderung fokus terhadap informasi terkait ancaman karir masa depan, seperti ketakutan akan kegagalan dalam pekerjaan maupun dalam hal akademik sehingga aktif dalam mengeksplorasi lingkungan sekitar guna mencari alternatif-alternatif pilihan karir dan mengurangi rasa cemas tersebut. Adapun faktor-faktor lainnya seperti individual difference maupun lingkungan pembelajaran turut menentukan tingkat kecemasan dalam menghadapi dunia kerja, misalnya individu yang merasa dapat mengontrol lingkungan pembelajaran agar memenuhi kebutuhan perkembangannya akan merasakan kecemasan yang lebih sedikit atau tidak cemas sama sekali juga hal tersebut dapat mengurangi kebimbangan karir, maka dari itu perlu bagi individu untuk meningkatkan perceived control dengan cara restrukturisasi keyakinan kausal melalui penyediaan informasi-informasi akurat dan intervensi oleh profesional sehingga memangkas pemikiran-pemikiran negatif terkait dunia kerja dan optimis dalam menentukan pilihan karir (Daniels et al., 2011).

Hasil penelitian yang telah dilakukan juga mengungkap bahwa tidak terdapat hubungan antara usia, universitas, fakultas dengan kematangan vokasional maupun kecemasan dalam menghadapi dunia kerja pada mahasiswa tingkat akhir. Pada beberapa penemuan tidak terdapat adanya hubungan antara usia maupun universitas dengan kematangan vokasional pada mahasiswa, dikarenakan pola pengalaman terkait vokasional yang dilalui oleh tiap mahasiswa di rentang usia berbeda cenderung sama meskipun dalam prosesnya merujuk pada tujuan yang berbeda. Sedangkan untuk kecemasan menghadapi dunia kerja pada mahasiswa tingkat akhir, ditemukan bahwa usia dan universitas tidak memegang peran yang signifikan, melainkan tingkat kecemasan tersebut berdasar pada tujuan dan strategi mahasiswa dimana dua hal itu dapat mempengaruhi lingkungan sekitar dan membantu mahasiswa untuk mengurangi tingkat kecemasan dalam menghadapi dunia kerja (Daniels et al., 2011).

Penelitian ini memiliki keterbatasan pada penyebaran data subjek yang tidak merata antara laki-laki dengan perempuan sehingga tidak dapat disebut representatif untuk mewakili satu jenis kelamin.

\section{Kesimpulan}

Hasil penelitian menunjukkan bahwa hipotesa yang telah diajukan dapat diterima, artinya terdapat hubungan yang signifikan antara kematangan vokasional dengan kecemasan dalam menghadapi dunia kerja pada mahasiswa tingkat akhir.

Penelitian ini dapat memperkuat penelitian sebelumnya yang menyatakan adanya hubungan antara kematangan vokasional dengan kecemasan dalam menghadapi dunia kerja pada mahasiswa tingkat akhir, selain itu dapat menjadi bahan acuan intervensi pengurangan kecemasan menghadapi dunia kerja pada individu yang berada dalam masa implementasi (usia 21-24 tahun). Berdasarkan hasil penelitian yang telah dilakukan pihak universitas harus memfasilitasi mahasiswa dalam mengembangkan diri dan menentukan pilihan karir, misalnya dengan mengadakan pelatihan kompetensi hingga membuka job fair bagi mahasiswa tingkat akhir, selain itu dibutuhkan sesi konseling maupun focused group discussion (FGD) mengenai dinamika karir individu guna memperjelas tujuan mahasiswa dan mengurangi kecemasan dalam menghadapi dunia kerja.

Rekomendasi kepada peneliti selanjutnya adalah mengambil sampel penelitian yang representatif dan merata, baik dari subjek laki-laki maupun perempuan kemudian membandingkan kematangan vokasional juga 
kecemasan dalam menghadapi dunia kerja antara lakilaki dengan perempuan, sehingga didapatkan gambaran perbedaan kematangan vokasional maupun kecemasan dalam menghadapi dunia kerja berdasarkan jenis kelamin.

\section{Referensi}

Bahrinsyah, F. R. (2018, February). Career maturity of guidance and counseling students at the Yogyakarta State University. In 1st International Conference on Education Innovation (ICEI 2017), 34-37. Atlantis Press.

Chen, J. Y. (2005). A study on college students' anxiety of career decision. Journal of Education \& Psychology, 28(4), 745771.

Crites, J. O. (2013). Career development in adolescence: Theory, measurement, and longitudinal findings. In Adolescence and Work (pp. 147-162). Routledge.

Daniels, L. M., Stewart, T. L., Stupnisky, R. H., Perry, R. P., \& LoVerso, T. (2011). Relieving career anxiety and indecision: The role of undergraduate students' perceived control and faculty affiliations. Social Psychology of Education, 14(3), 409-426. https://doi.org/10.1007/s11218-010-9151-x

Deer, L. K., Gohn, K., \& Kanaya, T. (2018). Anxiety and selfefficacy as sequential mediators in US college students' career preparation. Education+ training, 60(2), 187-197. https://doi.org/10.1108/ET-07-2017-0096

Eliana, R., Supriyantini, S., \& Tuapattinaja, J. M. (2016). Career maturity among high school students in medan. Advances in Social Science, Education and Humanities Research (ASSEHR), 81, 230-233. http://creativecommons. org/licenses/by-nc/4.0/

Feist, J., \& Feist, G. (2012). Teori kepribadian (7th ed.). Jakarta: Salemba Humanika.

Gash, N.-U.-A., \& Khan, N. (2014). Employability of vocational education stream subjects in kashmir: A comparative study. INSIGHT Journal of Applied Research in Education, 21(1), 130-135.

Gehlawat, M. (2019). Career maturity among adolescents in relation to their self-concept and anxiety. International Education \& Research Journal (IERJ), 5(2), 35-38.

Hammad, M. A. (2016). Future anxiety and its relationship to students attitude toward academic specialization. Journal of Education and Practice, 7(15), 54-65.

Hanifa, Y. (2017). Emotional quotient dan adversity quotient dengan kecemasan menghadapi dunia kerja. Psikoborneo: Jurnal Ilmiah Psikologi, 5(1), 43-55.

Harlow, A. J., \& Bowman, S. L. (2016). Examining the career decision self-efficacy and career maturity of community college and first-generation students. Journal of Career Development, 43(6), 512-525. https://doi.org/10. 1177/0894845316633780

Hartiningtyas, L., Purnomo, P., \& Elmunsyah, H. (2016). Hubungan antara self regulated learning dan locus of control internal dengan kematangan vokasional siswa smk. Jurnal Pendidikan: Teori, Penelitian, dan Pengembangan, 1(6), 1127-1136. http://dx.doi.org/10.17977/jp.v1i6.6457
Healy, C. (1991). Exploring a path linking anxiety, career maturity, grade point average, and life satisfaction in a community college population. Journal of College Student Development, 32(3), 207-211.

Hidayat, M., \& Alsa, A. (2018). The Effect of "PLANS" Training Towards Career Maturity of Senior High School Students. Journal of Educational, Health and Community Psychology, 7(2), 160-178.

Ismail, M. S., Abdullah, S. S., Mohamad, M. Z., \& Khairuldin, W. M. K. F. W. (2018). Student's career maturity: implications on career counselling. International Journal of Academic Research in Business and Social Sciences, 8(4), 887-897. http://dx.doi.org/10.6007/IJARBSS/v8-i4/4072

Kim, Y.-M., Kang, S.-C., Kwon, K.-N., Seo, Y.-J., Sung, S.H., Son, J.-L., . . . Kim, E.-H. a. (2018). Correlation between career satisfaction and career decision self-efficacy and career maturity of nursing students. Journal of Korean Clinical Health Science, 6(1), 1074-1082. https://doi.org/10. 15205/kschs.2018.03.31.1074

Lakesh, R., \& Khan, K. A. (2018). Gender and self-concept as predictors of career maturity. International Journal of Education and Management Studies, 8(1), 100-107. http: //www.iahrw.com/index.php/home/journal\$_\$detail/21\#list

Madan, C. R., \& Teitge, B. D. (2013, May 1). The benefits of undergraduate research: The student's perspective. The Mentor: An Academic Advising Journal. http://dus.psu.edu/ mentor/

Mahmud, M.S., Talukder, M.U., \& Rahman, S.M. (2020). Does "fear of covid-19' trigger future career anxiety? An empirical investigation considering depression from Covid-19 as a mediator. International Journal of Social Psychiatry, 67(1), 1-11. https://doi.org/10.1177/0020764020935488

McGowan, A. S. (1977). Vocational maturity and anxiety among vocationally undecided and indecisive students: The effectiveness of Holland's Self-Directed Search. Journal of Vocational Behavior, 10(2), 196-204. https://doi.org/10. 1016/0001-8791(77)90056-2

Mirah, F. F. E., \& Indianti, W. (2018). Pengaruh kecemasan karir terhadap commitment to career choice dengan kelekatan orang tua sebagai moderator. Jurnal Psikologi Insight, 2(1), 74-89. https://doi.org/10.17509/insight.v2i1.11947

Monks, F., Knoers, A., \& Haditono, S. R. (2001). Psikologi perkembangan: Pengantar dalam berbagai bagiannya. Yogyakarta: Gadjah Mada University Press.

Moshahid, M. (2017). Vocational Maturity of In-Service and PreService Secondary School Teachers: A Comparative Study. International Journal of Advanced Educational Research, 2(3), 14-17.

Nevid, J., Rathus, S., \& Greene, B. (2006). Psikologi abnormal (5th ed.). Jakarta: Erlangga.

Nurjanah, A. S. (2018). Kecemasan mahasiswa fresh graduate dalam melamar pekerjaan. Al-Ittizaan: Jurnal Bimbingan Konseling Islam, 1(2), 35-38. http://dx.doi.org/10.24014/0. 879160 
Patton, W., \& Creed, P. A. (2002). The relationship between career maturity and work commitment in a sample of Australian high school students. Journal of career development, 29(2), 69-85. https://doi.org/10.1023/A:1019981502852

Pisarik, C. T., Rowell, P. C., \& Thompson, L. K. (2017). A phenomenological study of career anxiety among college students. The Career Development Quarterly, 65(4), 339352. https://doi.org/10.1002/cdq.12112

Pratiwi, S. N., \& Irawati, W. (2020). Pengaruh career exploration terhadap career indecision yang dimediasi career anxiety mahasiswa diploma iii Fakultas Ekonomi dan Bisnis Universitas Syiah Kuala. Jurnal Manajemen Inovasi, 11(1), 97-111. https://doi.org/10.24815/jmi.v11i1.16537

Prideaux, L. A., \& Creed, P. A. (2001). Career maturity, career decision-making self-efficacy and career indecision: A review of the accrued evidence. Australian Journal of Career Development, 10(3), 7-12. https://doi.org/10.1177/ 103841620101000303

Pusparisa, Y. (2019, Mei 17). Angka pengangguran lulusan universitas meningkat. Retrieved from Kata Data Web Site: https://katadata.co.id/infografik/2019/05/17/angkapengangguran-lulusan-perguruan-tinggi-meningkat

Rohmatulloh, A. S. (2019). Pengaruh kematangan vokasional dan kemandirian menentukan karir terhadap adaptasi dunia kerja pada siswa kelas XII kompetensi keahlian teknik instalasi tenaga listrik di Kota Malang [Undergraduate thesis, Universitas Negeri Malang]. http://repository.um.ac.id/47957/

Rosliani, N., \& Ariati, J. (2017). Hubungan antara regulasi diri dengan kecemasan menghadapi dunia kerja pada pengurus ikatan lembaga mahasiswa psikologi Indonesia (ILMPI). Jurnal Empati, 5(4), 744-749.

Rozaini, N., \& Purba, L. C. (2018). Pengaruh hasil belajar komunikasi bisnis dan kematangan vokasional terhadap kesiapan. Niagawan, 7(1), 1-7. https://doi.org/10.24114/ niaga.v7i1.9348

Sari, D. Y., \& Astuti, T. P. (2014). Kecemasan dalam menghadapi dunia kerja ditinjau dari konsep diri pada mahasiswa tingkat akhir. Jurnal Empati, 3(4), 131-142.

Savickas, M. L. (1997). Career adaptability: An integrative construct for life-span, life-space theory. The Career Development Quarterly, 45(3), 247-259. https://doi.org/10. 1002/j.2161-0045.1997.tb00469.x

Savickas, M. L., \& Porfeli, E. J. (2012). Career adaptabilities scale: Construction, reliability, and measurement equivalence across 13 countries. Journal of vocational behavior, 80(3), 661-673. https://doi.org/10.1016/j.jvb.2012. 01.011 .

Schwartz, S. (2000). Abnormal psychology: A discovery approach. California: Mayfield Publishing Company.

Setiawan, W. V., Fattah, A. M., \& Puspitaningrum, A. (2019). The challenges of student in indonesia after college graduates with career choice start: Evidence from ten private universities in jakarta. The Winners, 20(2), 61-70. https://doi. org/10.21512/tw.v20i2.5674
Shamsuddin, A., Isa, K. H., Aziz, M. N., Mahfol, N. Z., \& Alagari, T. (2013). Graduate unemployment: The awareness and perception of graduates towards government's initiatives. International Journal of Business, Economics and Law, 3(1), $15-24$.

Shin, Y. J., \& Lee, J. Y. (2019). Self-Focused attention and career anxiety: The mediating role of Career adaptability. The Career Development Quarterly, 67(2), 110-125. https: //doi.org/10.1002/cdq.12175

Stead, G., \& Watson, M. (2006). Career psychology in the south african context (2nd ed.). Pretoria: Van Schaik.

Stuart, G. (2006). Buku saku keperawatan jiwa. Jakarta: EGC.

Sudira, P. (2012). Filosofi \& teori pendidikan vokasi dan kejuruan. Yogyakarta: UNY Press.

Sulistiani, W., Retno Suminar, D., \& Hendriani, W. (2019). The career adapt-abilities scale-Indonesian form: Psychometric properties and construct validity. Proceeding of the 4 th International Conference on Education, 4(2), 1-9.

Super, D. E., \& Kidd, J. M. (1979). Vocational maturity in adulthood: Toward turning a model into a measure. Journal of Vocational Behavior, 14(3), 255-270. https://doi.org/10. 1016/0001-8791(79)90054-X

Takil, N. B., \& Sari, B. A. (2021). Trait anxiety vs career anxiety in relation to attentional control. Current Psychology, 40(5), 2366-2370. https://doi.org/10.1007/s12144-019-0169-8

Tsai, C. T., Hsu, H., \& Hsu, Y. C. (2017). Tourism and hospitality college students' career anxiety: Scale development and validation. Journal of Hospitality \& Tourism Education, 29(4), 158-165. https://doi.org/10.1080/ 10963758.2017.1382365

Turner, S. L., \& Lapan, R. T. (2003). Native american adolescent career development. Journal of Career Development, 30(2), 159-172. https://doi.org/10.1023/A:1026116328826

Upadianti, L. P. S., \& Indrawati, E. S. (2020). Hubungan antara adversity intelligence dengan kecemasan menghadapi dunia kerja pada mahasiswa tingkat akhir departemen teknik perencanaan wilayah kota dan teknik ellektro universitas diponegoro. Empati, 7(3), 945-954.

Vignoli, E. (2015). Career indecision and career exploration among older French adolescents: The specific role of general trait anxiety and future school and career anxiety. Journal of Vocational Behavior, 89, 182-191. https://doi.org/10.1016/j. jvb.2015.06.005

Watkins, C., \& Campbell, V. (2000). Testing and assessment in counseling practice (contemporary topics in vocational psychology series). Mahwah: Lawrence Erlbaum Associates.

Widiyanto, I. (2008). Pointers: Metodologi penelitian. Semarang: BP Undip.

Xu, H., Hou, Z. J., Tracey, T. J., \& Zhang, X. (2016). Variations of career decision ambiguity tolerance between China and the United States and between high school and college. Journal of Vocational Behavior, 93, 120-128. https://doi.org/10.1016/ j.jvb.2016.01.007

Yunus, A. K., Benyamin, I., Marsuki, \& Fattah, S. (2017). Educated Unemployment in Indonesia: The Effects of 
Monetary Policy and Trade Openness. IOSR Journal of Economics and Finance, 8(2), 65-69.
Zunker, V. (2002). Career counseling: Applied concepts of life planning (6th ed.). California: Brooks/Cole-Thompson Learning. 